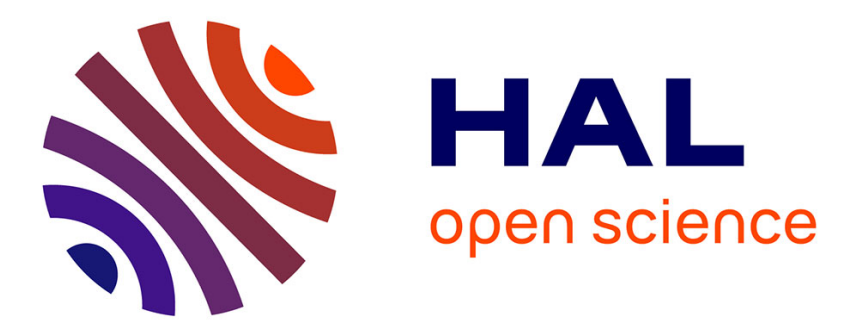

\title{
Strategic Factors to Obtain Competitive Advantage in Industries that Compete in Environmental Sustainability
}

Walter C. Satyro, Jose B. Sacomano, José Celso Contador

\section{To cite this version:}

Walter C. Satyro, Jose B. Sacomano, José Celso Contador. Strategic Factors to Obtain Competitive Advantage in Industries that Compete in Environmental Sustainability. IFIP International Conference on Advances in Production Management Systems (APMS), Sep 2016, Iguassu Falls, Brazil. pp.860867, 10.1007/978-3-319-51133-7_101 . hal-01615720

\section{HAL Id: hal-01615720 \\ https://inria.hal.science/hal-01615720}

Submitted on 12 Oct 2017

HAL is a multi-disciplinary open access archive for the deposit and dissemination of scientific research documents, whether they are published or not. The documents may come from teaching and research institutions in France or abroad, or from public or private research centers.
L'archive ouverte pluridisciplinaire HAL, est destinée au dépôt et à la diffusion de documents scientifiques de niveau recherche, publiés ou non, émanant des établissements d'enseignement et de recherche français ou étrangers, des laboratoires publics ou privés. 


\title{
Strategic Factors to Obtain Competitive Advantage in Industries that Compete in Environmental Sustainability
}

\author{
Walter C. Satyro, José B. Sacomano, and José Celso Contador \\ Paulista University, São Paulo, Brazil \\ \{satyro.walter, jbsacomano\}@gmail.com
}

\begin{abstract}
The objective of this paper is to present factors that can impact the strategy, responsible for the understanding of the competitive context, so that a business and operation strategy can be formulated to reach competitive advantage. These factors were identified in CAC Campos e Armas da Competicao (in Portuguese), Fields and Weapons of the Competition model of strategy formulation, and in the literature review. Using qualitative methodology supported on documentary research, we analyzed 10 industries listed in the BM\&FBOVESPA Stock Exchange, Sao Paulo, Brazil, that composes the ISE Index (Enterprise Sustainability Index), with an estimated total market value of US\$ 116 Billion based on October 2015. The results showed that the factors presented were used by these industries to formulate their strategies, but none used all of them. This research is designed for industries that compete in environmental sustainability..
\end{abstract}

Keywords: Strategy · Formulation · Sustainability · Advantage $\cdot$ Qualitative

\section{Introduction}

The industries are under pressure not only by the government policymakers, but also by the public, to be in line with the environmental politics $[1,2,3]$. In order to reduce their impact on the environment, the sustainable industries appeared, proposing to keep the production running with reduced environmental impact, that is, with lower consumption of energy, water, raw material, use of recycled material and minimum waste generated [4], using the cleaner production.

It is not easy for the sustainable industries to keep the competitiveness [5], since they need to invest to provide or buy technological innovation, new operation process and/or control, and at the same time maintain low costs to be competitive to remain in the market. Therefore, it is important that these sustainable industries can direct their strategies $[6,7]$ to reach competitive advantage.

To formulate a business and operation strategy that can reach competitive advantage it is necessary to understand the competitive context by analyzing 
the factors that can impact the strategy. Based on qualitative methodology supported on documental research, the objective of this study is to provide the factors responsible for the understanding of the competitive context, so that the executives, leaders, entrepreneurs, and the responsible for the management of the industries that compete in environmental sustainability can understand the competitive context, and so, more effectively, formulate a strategy that can bring competitive advantage.

\section{Literature Review}

\subsection{Sustainability and Sustainable Development}

It is complex to define sustainability [8,9] and some authors use sustainability as a synonym for sustainable development. The term triple bottom line was created by Elkington to show that sustainability must be analyzed under three spheres: environmental, social (or socio-cultural) and economic [10], as shown in Fig.1.

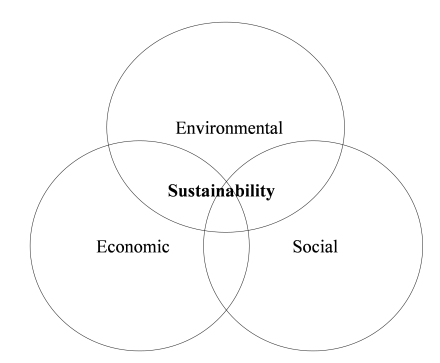

Fig. 1. The triple bottom line (Source: Adapted [10])

Sustainability is related to any human interaction with its environment [8], fostering business activities to fulfil the environmental, social, and economic requirement of the enterprise and its stakeholder for a longer period of time [11]. Other authors define sustainability as ways of making something sustainable [9], the use of resources in a way that allows them to regenerate and supply future generations [12], the ability of creating, testing and maintaining adaptive capacity, guided to the requirements of the ecosystem integrity and species diversity, also considering the social goals [13].

The term sustainable development was popularized in the report Our Common Future published in 1987 by the World Commission on Environment and Development, also known as the Brundtland Report, in which sustainable development is defined as "development which meets the needs of the present without compromising the ability of future generations to meet their own needs" [14]. The sustainable development is a way, a process to reach the target that is sustainability [15]. 


\subsection{CAC - Campos e Armas da Competicao Model (Fields and Weapons of the Competition)}

Designed by Contador [16], CAC - Campos e Armas da Competicao (in Portuguese), Fields and Weapons of the Competition model was based on quantitative and qualitative extensive research to understand why some companies are more competitive than others.

The central point of the CAC model is that, for a company to gain competitiveness, it is necessary to have high performance only in the few weapons of the competition that can give to this company some competitive advantage in the competition field selected for each pair product/market [16].

- Field of the competition is the imaginary locus, where products or companies dispute the preference of the customer, in which the companies seek to maintain or reach competitive advantage, such as short delivery time or innovative products [16];

- Weapons of the competition are the resources and capacities held by the company to maintain/achieve competitive advantage, such as technological control of the production processes and information system [16];

- Competitive advantage is a position of superiority recognized and valued by the customer, that leads a company to have a better competitiveness than itself in the past, or than its competitors; it is reached by a conjunction of some fields of the competition [16].

It is also important to present two other constructs of CAC: 1) Intensity of the weapons is the ability of the use of the weapon, or the power of a weapon, assessed at five levels, and 2) Relevant weapons of a company are the subset of the weapons that can furnish high competitive advantage to compete in a selected field, that must have a high level of intensity and, if necessary, investment shall be made to reach competence [16].

The formulation of competitive business strategy by CAC is to divide the market in segments, to establish the right product to the right segment and to select one or two fields of the competition, as well as one or two adjuvant fields of the competition for each pair product/market [16].

\section{Methodology}

We used a literature review and documentary research for analysis to find the factors that can impact the strategy, responsible for the understanding of the competitive context so that business and operation strategy can be formulated to reach competitive advantage.

The literature review started with the analysis of 54 papers published in the Journal of Cleaner Production number 96, 2015, that presented the best papers submitted to the 4th International Workshop Advances in Cleaner Production, held in Sao Paulo, Brazil, 2013, with the theme "Integrating cleaner production 
into sustainability strategies"; we selected 8 papers that presented some of these factors in their researches, as shown in Fig. 2.

In these papers we could notice that the authors analyzed the strategy formulation under many aspects, but none of them gave a guidance that could help the responsible for the strategy formulation to understand the competitive context and so formulate a strategy that could lead to a competitive advantage, what is a gap.

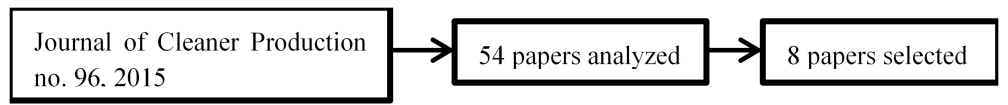

Fig. 2. Initial literature review (Source: Authors)

We continued the literature review to find the factors responsible for the understanding of the competitive context, using EBSCO, ScienceDirect, Web of Science, and with the study of environmental standard ISO/NBR 14000:2015. We analyzed a total of 101 papers and selected 55 of them, where these factors were presented. Identified these factors, we made a research to analyze empirically if these factors were used to formulate a strategy possible to reach competitive advantage.

The selected group of research was constituted by 10 industries, listed and classified as industry by BM\&FBOVESPA Stock Exchange, Sao Paulo, Brazil that composes the ISE Index (Enterprise Sustainability Index). The ISE was the 4th sustainability index released worldwide, which comprises 51 stocks from 40 Brazilian companies, publicly traded, listed on BM\&FBOVESPA, among the issuing stocks of the 200 most liquid shares on the BM\&FBOVESPA Stock Exchange [17].

Their names and sector of activities are presented in Table 1. The abbreviation "S.A." means publicly traded companies in Portuguese. We evaluated these 10 industries by their 2015 Sustainability Report, studying if the factors identified in the literature review were present and were used for the understanding of the competitive context.

\section{Results}

The factors identified in this research are presented below.

\subsection{The Strategic Factors of the Business Strategy}

The factors necessary for understanding the competitive context of the business strategy identified in the CAC model of strategy formulation and in the literature review were: Customers; Shareholders; Competitors/Newcomers; Board, Intensity of the Relevant Weapons; Interorganizational Networks; Labor Unions; 
Table 1. The public companies under research and estimated total market value. Source: Adapted [18]

\begin{tabular}{cccc}
\hline Public Companies & Sectors of Activities & $\begin{array}{c}\text { No. of Pages } \\
\text { Analyzed }\end{array}$ \\
\hline 1 & BRF S.A. & Processed Food & 117 \\
2 & BRASKEM S.A. & Chemicals & 182 \\
3 & DURATEX S.A. & Wood and Paper & 172 \\
4 & EMBRAER S.A. & Transport Material & 88 \\
5 & FIBRIA S.A. & Wood and Paper & 152 \\
6 & GERDAU S.A. & Steel/Metallurgy & 49 \\
7 & KLABIN S.A. & Wood and Paper & 63 \\
8 & NATURA S.A. & Personal and Cleaning Products & 128 \\
9 & VALE S.A. & Mining & 119 \\
10 & WEG S.A. & Machines and Equipment & 162 \\
\multicolumn{2}{c}{ Estimated Total Market Value (Oct., 2015): US\$ 116 Billion Total: 1,232 pages } \\
\hline
\end{tabular}

Economy; Special Interests Group; Media; Supply Chain; Government / Regulatory Agencies; Climatic, Geographic and/or Geological Conditions; Natural Resources / Raw Material; Internationalization; Sustainable Development / Environmental Protection; Substitute Products; New Technologies; Research, Development and Innovation; Quality of Products; Values; Organizational Culture; Competencies/Know-how; Power and Logistics.

\subsection{The Strategic Factors of the Operation Strategy}

These ten industries focused on operation strategy identified with a cleaner production, and at the same time they needed to control their costs and other internal factors to keep the competitiveness in a market each time more globalized and competitive. The factors identified were: Reduction of Water and Energy Consumption; Occupational Safety and Health Management; Process Safety; Efficiency of Material and Resources; Eco-efficiency; Renewable Raw Material; Waste and Liquid Effluent Reduction; Greenhouse Gases Reduction; Reverse Logistics; and Recycling.

\subsection{Competitive Context of the Business Strategy}

Despite all these ten industries have emphasized in their Sustainability Report, which they have to issue yearly, their concern for the customer, only $30 \%$ put them as a central point to reach competitive strategy. Shareholders and board are important factors for $100 \%$ of these industries, but none of them analyzed potential competitors or newcomers, and $10 \%$ of these industries not even mentioned the competitors as an important factor of analysis.

All these industries took into account the following factors: Intensity of the Relevant Weapons (resources managed by the company); Interorganizational 
Networks (various associations to which the company belongs); Labor Unions (representing the interests of the workers); and Interest Groups that might affect or be affected by the company. The Economic and Financial factors were used by $60 \%$ of these public companies issuing an additional financial report to supplement the Sustainability Report. The term "company sustainability" was used by $20 \%$, instead of sustainable company, expressing more concern with their companies per se than with environmental sustainability.

Despite $100 \%$ of the industries in analysis have emphasized the Media factor, none of them formally reported the use of social networks. Supply Chain; Government/ Regulatory Agencies; Natural Resources / Raw Material; and Sustainable Development / Environmental Protection were factors considered by all of them. Climatic conditions that take into account the rain standard, or other climatic changes as well as Geographic and/or Geological conditions that can provide more stable and fertile soil with reduced probability of floods or landslip were factors considered by $100 \%$ of these industries.

The Internationalization factor was subject of interest by $100 \%$ of them that have factories, branches or offices overseas, as well as the importance of the logistic factor to conduct all these operations closer to a harmony. Only $10 \%$ took into account the Substitute Products factor that can cause impact in the competitiveness of their products; in contrast to this, $100 \%$ of these industries reported their emphasis on Innovation, New Technologies, Research and Development as a competitive differential. All these public companies took into account the Quality of their products, as well as their Internal Values, Organizational Culture, Know-How and Skills. Only 10\% of these industries took into account the Power factor, and the remaining $90 \%$ did not even mention Power as an important factor of analyzes.

\subsection{Competitive Context of the Operation Strategy}

These ten public companies showed that all of them had in their operation strategy the emphasis in the Reduction of Water Consumption and Energy factor. In Brazil the hydroelectric plants are responsible for $65 \%$ of the energy matrix of the country [19,20]; and in 2015 Brazil was in the middle of a hydric crisis [21] affecting the supply of water and energy at the same time.

Occupational Safety and Health Management were also factors taken into account in operation strategy for all these industries surveyed, however, only $30 \%$ of the industries mentioned concern for the Safety of the Production Process. Efficiency of Materials and Resources, understood as efficient use of raw materials and resources were mentioned by $60 \%$ of these industries; considering that these industries compete on environmental sustainability, it would be expected a higher percentage of industries adopting this operation strategy factor.

Only $10 \%$ of the industries investigated did not care about Eco-efficiency - an initiative that stimulates business to seek economic benefits using environmental improvements [22] - in its sustainability report. The use of Renewable Raw Material factor was an operational strategy used by $60 \%$ of the industries in the research. Waste (solid, liquid and pasty) and the Liquid Effluent Reduction were 
operational strategies used by $90 \%$ of these industries; the Greenhouse Gases Reduction was not mentioned by $10 \%$. Reverse Logistics was used only by $30 \%$ and Recycling was present in $70 \%$ of the operational strategies.

\section{Conclusions}

The objective of this research was to present factors that are important to take into account to understand the competitive context of the business and operation strategy for industries that compete in environmental sustainability. These factors were identified in CAC - Campos e Armas da Competicao (in Portuguese), Fields and Weapons of the Competition model of strategy formulation, and in literature review. These factors were analyzed in 10 industries listed in the BM\&FBOVESPA Stock Exchange, Sao Paulo, Brazil that composed the ISE Index (Enterprise Sustainability Index), by their 2015 Sustainability Report [17]. The research showed that the factors proposed were used by these industries, but none used all of them.

These industries took into account Climatic, Geographical and Geological Factors, and also tried to promote the Sustainable Development, investing in New Technologies, Innovation, Research and Development, as well as Quality, but also considering their individual Values, Organizational Culture, Know-How and Skills. Just $10 \%$ of these industries took into account the Substitute Products factor that can impact the competitiveness of their products, and $90 \%$ did not consider Power as a factor of strategic analysis.

These industries were trying to reduce Waste (solid, liquid and pasty) and the Liquid Effluent, as well as seeking to reduce Waste generation, Water and Energy consumption, to reach the eco-efficiency [22]; however, only $30 \%$ of these industries emphasized the Safety of the Production Process and practiced Reverse Logistic, and just 10\% did not even mention Greenhouse Gases Reduction $[12,13]$ in their operation strategy in their Sustainability Report. The relevance of this research was to provide guidance for strategy formulation that can bring competitive advantage for industries [16]; as a limitation of this research the factors presented here were designed for industries that compete in environmental sustainability, so we suggest the use of these factors to analyze industries that compete in other fields to compare the results.

\section{Acknowledgment}

We thank the Coordenação de Aperfeicoamento de Pessoal de Nivel Superior (CAPES), Ministry of Education, Brazil, for the research grant.

\section{References}

1. Climateaction: http://www.climateactionprogramme.org/news/cop21_kicks_ off_in_paris 
2. Climateaction: http://www.climateactionprogramme.org/news/un_chief_ hails_opening_week_of_cop21?utm_source=Feeds\&utm_campaign=News\&utm _ medium=rss

3. Wang, Z., Subramanian, N., Gunasekaran, A., Abdulrahman, M.D., Liu, C.: Composite Sustainable Manufacturing Practice and Performance Framework: Chinese Auto-parts Suppliers Perspective. International Journal of Production Economics 170, 219-233 (2015)

4. Council, N.R.D.: http://www.nrdc.org/health/climate/airpollution.asp

5. Taisch, M., Stahl, B., May, G.: Sustainability in Manufacturing Strategy Deployment. Procedia CIRP 26, 635-640 (2015)

6. Robert, K.H., Schmidt-Bleek, B., De Larderel, J.A., Basile, G., Jansen, J.L., Kuehr, R., Thomas, P.P., Suzuki, M., Hawken, P., Wackernagel, M.: Strategic Sustainable Development - Selection, Design and Synergies of Applied Tools. Journal of Cleaner production 10(3), 197-214 (2002)

7. Almeida, C., Agostinho, F., Giannetti, B., Huisingh, D.: Integrating Cleaner Production Into Sustainability Strategies: An Introduction to This Special Volume. Journal of Cleaner Production 96, 1-9 (2015)

8. Marcelino-Sádaba, S., González-Jaen, L.F., Pérez-Ezcurdia, A.: Using Project Management as a Way to Sustainability. From a Comprehensive Review to a Framework Definition. Journal of cleaner production 99, 1-16 (2015)

9. Mishra, S.P., Mohanty, A.K., Mohanty, B.: Are There Dominant Approaches to Strategy Making? Vilakshan: The XIMB Journal of Management 12(1) (2015)

10. Elkington, J.: Enter the Triple Bottom Line. In: Henriques, A., Richardson, J. (eds.) The triple bottom line: Does it all add up. Routledge (2004)

11. Anåker, A., Elf, M.: Sustainability in Nursing: A Concept Analysis. Scandinavian journal of caring sciences 28(2), 381-389 (2014)

12. Bansal, T, Desjardine, M.: http://iveybusinessjournal.com/ dont-confuse-sustainability-with-csr/

13. Harris, J.M.: Sustainability and Sustainable Development. International Society for Ecological Economics 1(1), 1-12 (2003)

14. WCED: (1987), http://www .un-documents .net/our-common-future.pdf

15. Korhonen, J.: From Material Flow Analysis to Material Flow Management: Strategic Sustainability Management on a Principle Level. Journal of Cleaner Production 15(17), 1585-1595 (2007)

16. Contador, J.C.: Campos e Armas da Competicao. Saint Paul, São Paulo (2008)

17. BMF\&FBOVESPA: http://www. bmf bovespa.com.br/indices/ResumoIndice. aspx? Indice $=$ ISE\&Opcao $=0 \&$ idioma $=p t-b r$

18. BMF\&FBOVESPA: http://www.bmfbovespa.com.br/indices/ ResumoCarteiraTeorica . aspx? Indice=ISE\&idioma=pt-br

19. National Agency of Electric Energy of Brazil: http://www.aneel.gov.br/ aplicacoes/capacidadebrasil/capacidadebrasil.cfm

20. TERMOPE Neoenergia Group: http://www.termope.com.br/Pages/0\%20Setor $\%$

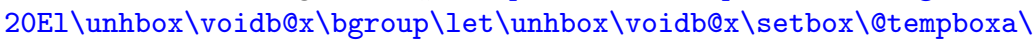
hbox $\{\mathrm{e} \backslash \mathrm{gl}$ lobal $\backslash$ mathchardef $\backslash$ accent@spacef actor $\backslash$ spacefactor $\} \backslash$ accent $19 \mathrm{e} \backslash$ egroup \spacefactor \accent@spacefactortrico/matriz-energetica.aspx

21. National Agency of Water of Brazil: http://www2.ana.gov.br/Paginas/ imprensa/noticia. aspx?List $=c c b 75 a 86-b d 5 a-4853-8 c 76-c c 46 b 7 d c 89 a 1 \& I D=$ 12684

22. World Business Council for Sustainable Development: http://www.wbcsd.org/ pages/EDocument/EDocumentDetails . aspx? ID=13593 